\title{
A novel method for cell counting of Microcystis colonies in water resources using a digital imaging flow cytometer and microscope
}

\author{
Jungsu Park', Yongje Kim², Minjae Kim³, Woo Hyoung $\mathrm{Le}^{2^{+}}$ \\ ${ }^{1}$ Water Quality Research Center, Korea Water Resources Corporation, Daejeon 34350, Republic of Korea \\ ${ }^{2}$ Department of Civil, Environmental and Construction Engineering, University of Central Florida, 12800 Pegasus Dr., Suite 211, Orlando, Florida \\ 32816-2450, USA \\ ${ }^{3}$ School of Life Science, Kyungbook National University, Daegu 41566, Republic of Korea
}

\begin{abstract}
Microcystis sp. is one of the most common harmful cyanobacteria that release toxic substances. Counting algal cells is often used for effective control of harmful algal blooms. However, Microcystis sp. is commonly observed as a colony, so counting individual cells is challenging, as it requires significant time and labor. It is urgent to develop an accurate, simple, and rapid method for counting algal cells for regulatory purposes, estimating the status of blooms, and practicing proper management of water resources. The flow cytometer and microscope (FlowCAM), which is a dynamic imaging particle analyzer, can provide a promising alternative for rapid and simple cell counting. However, there is no accurate method for counting individual cells within a Microcystis colony. Furthermore, cell counting based on two-dimensional images may yield inaccurate results and underestimate the number of algal cells in a colony. In this study, a three-dimensional cell counting approach using a novel model algorithm was developed for counting individual cells in a Microcystis colony using a FlowCAM. The developed model algorithm showed satisfactory performance for Microcystis sp. cell counting in water samples collected from two rivers, and can be used for algal management in fresh water systems.
\end{abstract}

Keywords: Algae, Algal cell counting, FlowCAM, Harmful algal bloom, Microcystis

\section{Introduction}

Harmful algal blooms (HABs) are the rapid growth of microscopic algae that can cause harm to animals, people, and the local environment. Thus, determining the physiological status of algal growth is important for effective water quality and algal bloom management in freshwater environments [1]. Particularly, Microcystis sp. is one of the most common harmful cyanobacteria found in freshwater [2-6]; they produce toxic substances, namely microcystins, which are known to cause serious damage to the human liver [7-9]. Proper management of Microcystis sp. is important for securing safe water for the public [7, 10-12]. Biomass, cell density, and chlorophyll- $a$ concentrations are often measured to estimate the status of algal growth [1, 13-17]. Counting algal cells is also important for determining the status of eutrophication in water bodies worldwide, as cell number is often included in

This is an Open Access article distributed under the terms of the Creative Commons Attribution Non-Commercial License (http://creativecommons.org/licenses/by-nc/3.0/) which permits unrestricted non-commercial use, distribution, and reproduction in any medium, provided the original work is properly cited.

Copyright (C) 2019 Korean Society of Environmental Engineers guidelines for algal regulation, such as the World Health Organization guideline [18-20]. For example, in South Korea, Microcystis sp. is regulated based on the total number of cells within a colony of Microcystis sp. (cells $/ \mathrm{mL}$ ). Microscopic investigation is widely used for counting algal cells; however, it is a time-consuming, subjective, and labor-intensive method. Given that HABs are an increasing global issue, it is urgent to develop a simple, rapid, and accurate analytical method for enumerating the individual cells in an algal colony.

The FlowCAM (Flow Cytometer and Microscope, Fluid Imaging Technologies, Yarmouth, ME, USA) is a potential alternative to the conventional cell counting method [21] that has been widely used for the identification, classification, and biomass measurement of algae in water bodies by providing unbiased results within a relatively short time (e.g., within $5 \mathrm{~min}$ ) [22-24]. Rowe et al. captured images of individual colonies of Microcystis sp. in western Lake

\author{
Received July 31, 2018 Accepted September 30, 2018 \\ ${ }^{\dagger}$ Corresponding author \\ Email: woohyoung.lee@ucf.edu \\ Tel: +1-407-823-5304 Fax: +1-407-823-3315 \\ ORCID: 0000-0002-5298-2371
}


Erie, United States using a FlowCAM, and estimated their equivalent spherical diameters using image analysis [4]. The FlowCAM is a particle image analyzer that was originally developed for the analysis of various particulate matters in water, including zooplankton and phytoplankton [25-28]. It identifies algae based on shape and morphological parameters of algal images, such as length, width, area, area-based diameter, and equivalent spherical diameter, which are obtained from a microscope and a digital camera equipped in the FlowCAM imaging platform [23, 25]. By processing FlowCAM images, a photo image library for algal samples is generated by users, and the characterized shapes and morphological parameters of algal images are used for the proper identification and classification of algal species in unknown water samples [24]. Thus, the acquisition of discriminable image pools of target algal species is essential for accurate measurement of algal cell counts.

Although the FlowCAM provides valuable information on algal communities, there are still limitations in counting individual cells within a Microcystis sp. colony, which is essential for the management of drinking water resources. The FlowCAM analyzes two-dimensional (2D) surface areas. If algae are not distributed in the form of single cells (e.g., algal aggregates or clumps), then this 2D cell counting method will be biased. This may result in underestimation of the total number of algal cells. To overcome this, Wang et al. [14] employed sonication or alkaline hydrolysis to disintegrate the algal colonies, and measured unicellular Microcystis using a FlowCAM. However, there is still a lack of image processing techniques, which are required to improve the accuracy of algal cell measurements using a FlowCAM.

To the best of our knowledge, there is no standard procedure for counting the individual cells in a 3D Microcystis colony using a FlowCAM. In this study, we developed a novel method for automated quantification of Microcystis cells in fresh water using a FlowCAM. The purpose of this study was to verify the applicability of the method in practical cell counting of Microcystis colonies for water quality management rather than to provide specific param- eters of the developed method. First, Microcystis colonies within a water sample were identified using a FlowCAM with a local FlowCAM image library of Microcystis colonies collected in this study from fresh water of rivers and reservoirs in South Korea. Second, the total sum of the areas of the Microcystis colonies within the water sample was obtained from the FlowCAM, and then a model algorithm (i.e., the relationship between the number of cells vs. the $2 \mathrm{D}$ surface area of the algal colonies) developed in this study was applied to estimate the total number of individual cells of Microcystis sp. within the water sample. The accuracy of the model algorithm in counting the total number of individual cells in Microcystis colonies within the water sample was then evaluated by comparing the result from the FlowCAM with the result from a conventional microscopic method for algal cell counting.

\section{Materials and Methods}

\subsection{Development of a FlowCAM Image Library for Microcystis sp.}

Currently, there are no sufficient FlowCAM libraries available for the identification of Microcystis sp. found in major rivers in South Korea; thus, in this study, a specific image library of Microcystis sp. from Korean rivers was developed. A FlowCAM (8100-C, Fluid Imaging Technologies Inc., Scarborough, ME, USA) was used to generate the image library of Microcystis sp. in water samples collected from two of four major rivers, namely the Nakdong River and the Geum River, in South Korea between June 27 and August 16, 2017 (Fig. 1 and Table 1(a)), where algal blooms have been an important issue in water quality management [29]. The water samples were collected from the surface of the two rivers.

The Nakdong River is the longest river in South Korea with a flow path length of $510 \mathrm{~km}$ and a watershed area of about $23,000 \mathrm{~km}^{2}$. There are eight weirs in the middle of the river,

Table 1. Sampling Sites

(a) Sampling Sites for the Development of the Microcystis sp. Library

\begin{tabular}{lcccc}
\hline Watershed & Site & Latitude (N) & Longitude (E) & Sampling date \\
\hline \multirow{3}{*}{ Nakdong River } & Dalsung Weir & $35^{\circ} 44^{\prime} 13^{\prime \prime}$ & $128^{\circ} 24^{\prime} 44^{\prime \prime}$ & July 25,2017 \\
& Hapcheon-changnyeong Weir & $35^{\circ} 35^{\prime} 43^{\prime \prime}$ & $128^{\circ} 21^{\prime} 17^{\prime \prime}$ & June 27,2017 \\
& Changnyeong-haman Weir & $35^{\circ} 22^{\prime} 55^{\prime \prime}$ & $128^{\circ} 32^{\prime} 49^{\prime \prime}$ & June 27,2017 \\
\hline Geum River & Busan & $35^{\circ} 12^{\prime} 15^{\prime \prime}$ & $128^{\circ} 59^{\prime} 33^{\prime \prime}$ & July 19, 2017 \\
\hline
\end{tabular}

(b) Sampling Sites for Determining the Relationship between FlowCAM Images and the Cell Counting Model Algorithm

\begin{tabular}{|c|c|c|c|c|c|}
\hline Watershed & Sit & & Latitude $(\mathrm{N})$ & Longitude (E) & Sampling date \\
\hline Nakdong River & Gangjeong-go & Weir & $35^{\circ} 50^{\prime} 36^{\prime \prime}$ & $128^{\circ} 27^{\prime} 24^{\prime \prime}$ & August 8, 2017 \\
\hline \multirow{6}{*}{ Geum River } & \multicolumn{2}{|c|}{ Baekje Weir } & $36^{\circ} 19^{\prime} 15^{\prime \prime}$ & $126^{\circ} 56^{\prime} 38^{\prime \prime}$ & September 7, 2017 \\
\hline & \multirow{5}{*}{ Daecheong Dam } & Site 1 & $36^{\circ} 22^{\prime} 24^{\prime \prime}$ & $127^{\circ} 33^{\prime} 29^{\prime \prime}$ & August 31, 2017 \\
\hline & & Site 2 & $36^{\circ} 22^{\prime} 05^{\prime \prime}$ & $127^{\circ} 33^{\prime} 39^{\prime \prime}$ & August 31, 2017 \\
\hline & & Site 3 & $36^{\circ} 21^{\prime} 35^{\prime \prime}$ & $127^{\circ} 33^{\prime} 39^{\prime \prime}$ & August 16 and 31, 2017 \\
\hline & & Site 4 & $36^{\circ} 21^{\prime} 20^{\prime \prime}$ & $127^{\circ} 33^{\prime} 36^{\prime \prime}$ & August 16, 17, and 31, 2017 \\
\hline & & Site 5 & $36^{\circ} 20^{\prime} 59^{\prime \prime}$ & $127^{\circ} 33^{\prime} 39^{\prime \prime}$ & August 16 and 31, 2017 \\
\hline
\end{tabular}




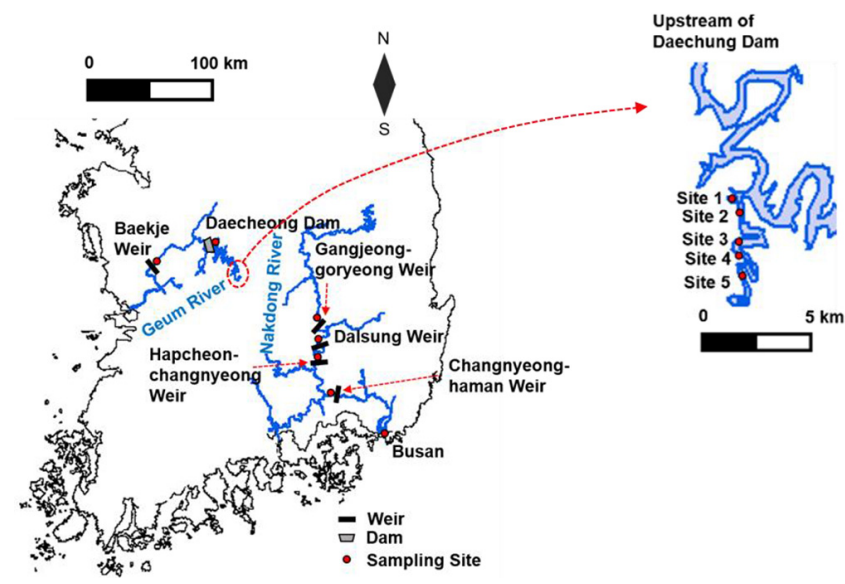

Fig. 1. Research sites and sampling locations in the Nakdong River and Geum River in South Korea.

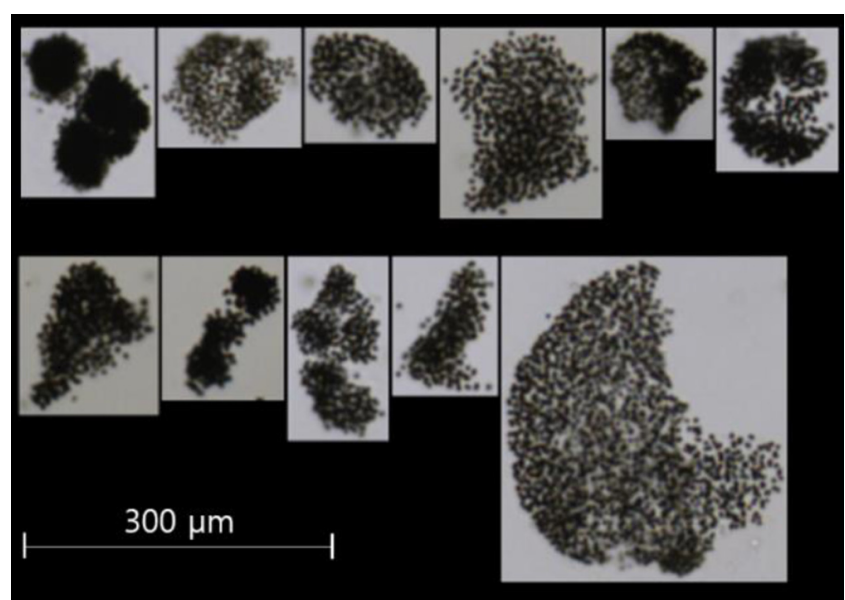

Fig. 2. Representative FlowCAM images of Microcystis colonies $(<300$ $\mu \mathrm{m}$ in diameter) obtained from the water samples from the Nakdong River and Ceum River in South Korea during the summer season in 2017.

which were built in 2011. The Geum River is the third longest river in Korea with a flow path of length of $400 \mathrm{~km}$ and a watershed area of about $9,885 \mathrm{~km}^{2}$. The Daecheong Dam is located about $135 \mathrm{~km}$ upstream of the mouth of the Geum River, and has a storage capacity of 1.5 billion tons and a watershed area of 4,100 $\mathrm{km}^{2}$. It was built in 1980 to provide drinking water and to manage floods during the summer season.

A total of 2,520 photo images of Microcystis colonies were obtained using a FlowCAM from the samples that were randomly collected from four sites in the Nakdong River, namely the Dalsung Weir (July 25, 2017), Hapcheon-changnyeong Weir (June 27, 2017), Changnyeong-haman Weir (June 27, 2017), Busan (July 19, 2017), and one site at about $35 \mathrm{~km}$ upstream of the Daecheong Dam (August 16, 2017) in the Geum River (Fig. 2). The FlowCAM identifies algal images when a water sample flows through a filter tube inside the device where the diameter of the filter tube is coupled with a specific magnification (e.g., $300 \mu \mathrm{m}$ tube filter with $\times 400$ magnification or $600 \mu \mathrm{m}$ tube filter with $\times 200$ magnifi- cation) for cell counting. In this study, $300 \mu \mathrm{m}$ tube filter connected with a microscope $(\times 400)$ was used as it typically covers most dominant sizes of colonies found in water. The colonies larger than $300 \mu \mathrm{m}$ in diameter were filtered to prevent clogging in the FlowCAM filter tube, and thus were excluded from the library. Approximately $60 \%$ of the photo images $(1,500)$ were taken from the samples collected in the Nakdong River, and the rest were from the samples collected in the Daecheong Dam. The 2,520 photo images were utilized for the development of a library of FlowCAM images that was used for the identification and classification of Microcystis colonies in unknown water samples.

\subsection{Colony Surface Areas and Number of Cells in a Colony}

Water samples collected from the Daecheong Dam (Site 4) in the Geum River between August 16 and 17, 2017 were used to develop a model algorithm for the cell count of Microcystis colonies (Fig. 1). A total of 55 Microcystis colonies were analyzed to determine the relationship between the $2 \mathrm{D}$ surface area of a colony and the number of cells in each colony. For visual identification of cell numbers using a conventional microscopic method, individual Microcystis sp. cells were counted under a microscope ( $\times 400$, Nikon DS-Ri2, Tokyo, Japan). It should be noted that this method counted only individual cells, which were identified under a microscope with 2D images, and was expected to underestimate the actual number of cells. The area of a single Microcystis colony ranged from $579 \mu^{2}$ to $39,029 \mu \mathrm{m}^{2}$ (Fig. 3). Then, a model algorithm was developed from the relationship between the number of cells and the area of the colony.

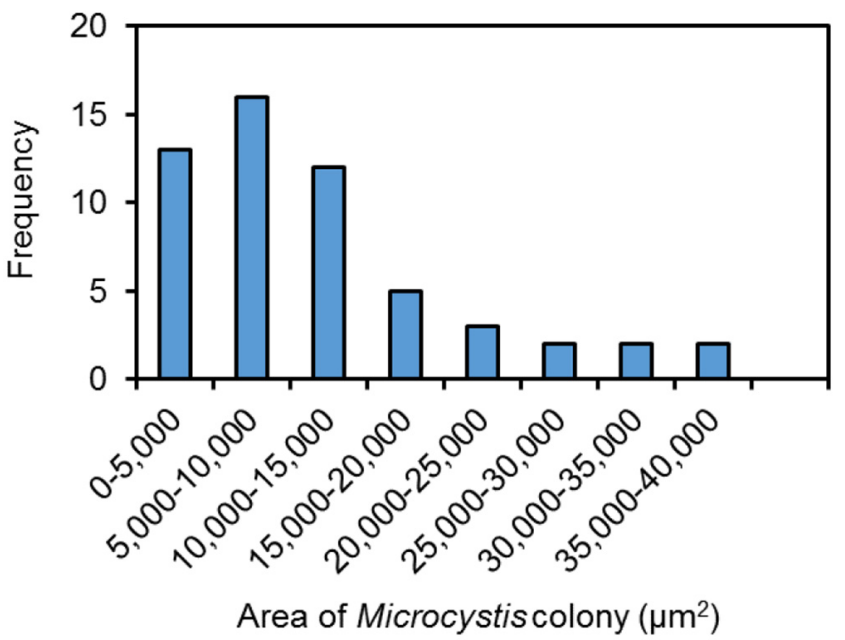

Fig. 3. Size distribution of the area of Microcystis colonies.

\subsection{Determination of Relationship between FlowCAM Images and the Cell Counting Model Algorithm}

For cell number counting by FlowCAM analysis, the FlowCAM was first used for the identification of Microcystis colonies in a water sample (e.g., $5 \mathrm{~mL}$ ). It then calculated the surface area of the 2D Microcystis colony and determined the cell numbers using the relationship between the number of cells in the 
Microcystis colony and the surface area of the Microcystis colony, which was developed by counting the cells in each colony in the 2D image, as explained in Section 2.2.

To evaluate the developed model algorithm for Microcystis sp. cell counting, unknown water samples randomly collected from the two rivers (Fig. 1 and Table 1(b)) were analyzed by comparing cell numbers between a conventional microscopic method and the FlowCAM method (Fig. 4). A total of 26 samples collected from the Daecheong Dam in the Geum River (August 16, 17, and 31, 2017), one sample from the Baekje Weir in the Geum River (September 7, 2017), and one sample from the Gangjeong-goryeong Weir in the Nakdong River (August 8, 2017) were separately used to evaluate the uncertainty of the developed model algorithm. For weirs, water samples were collected about $500 \mathrm{~m}$ upstream of each weir body. Water samples at the Daecheong Dam were randomly collected from five different sites between 30 and $36 \mathrm{~km}$ upstream of the dam body. Five milliliters of each sample were analyzed using the FlowCAM, and the number of cells (cells $/ \mathrm{mL}$ ) was compared between the FlowCAM method and visual inspection with a conventional microscope to determine the accuracy of the model algorithm developed in this study.

The conventional microscopic method measured only the cells that were identifiable in 2D. Thus, individual cell counting of a Microcystis colony was almost impossible without breaking the colony because the colony was a 3D shape. For visual identification in this step, individual Microcystis cells were counted using a conventional microscopic method using a Sedgewick-Rafter counting chamber after disintegration of the Microcystis colony by sonicating $1 \mathrm{~mL}$ of the water sample for $10-20 \mathrm{~min}$ at 28 $\mathrm{kHz}$ and $80 \mathrm{~W}$ using an ultrasound device (Ultrasonic Processor CS-1025, Chosun 21, Seoul, South Korea) with the addition of $100 \mu \mathrm{L}$ of $1 \mathrm{M} \mathrm{NaOH}[14,30,31]$. The sonification time was

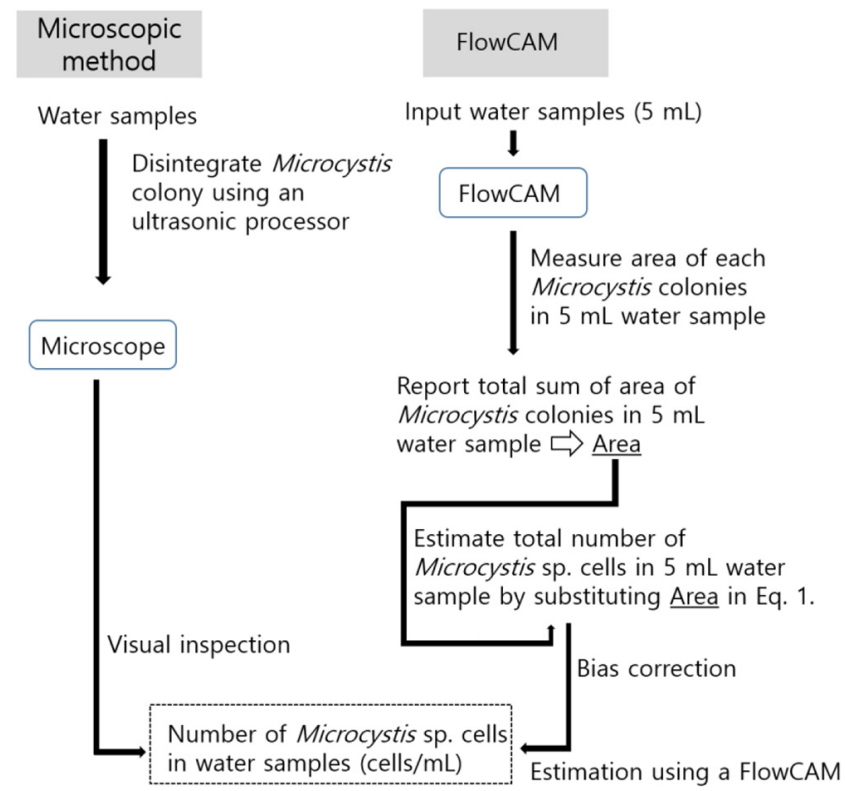

Fig. 4. Comparison of Microcystis sp. cell counting procedures of microscopy and the FlowCAM. determined based on preliminary tests by monitoring Microcystis colony disintegration under the conventional microscope after sonication $(28 \mathrm{kHz}$ and $80 \mathrm{~W})$ with different durations.

\section{Results}

\subsection{Relationship between Number of Cells in a Colony and Colony Areas}

The relationship between the number of cells in a Microcystis colony and the surface area of the colony is shown in Fig. 5. A linear regression model (Eq. (1)) showed a relatively strong relationship between cell numbers and surface area measured by visual inspection using microscopy, with a coefficient of determination $\left(\mathrm{R}^{2}\right)$ of 0.93 .

$$
\begin{aligned}
& \text { Number of cells in a Microcystis colony (cells) }= \\
& 0.044 \times \text { surface area }\left(\mu m^{2}\right)
\end{aligned}
$$

where surface area is the surface area of a Microcystis colony in a water sample $\left(\mu \mathrm{m}^{2}\right)$. As the number of cells should be zero when the area of a colony is zero, the intercept of the model equation was determined as zero.

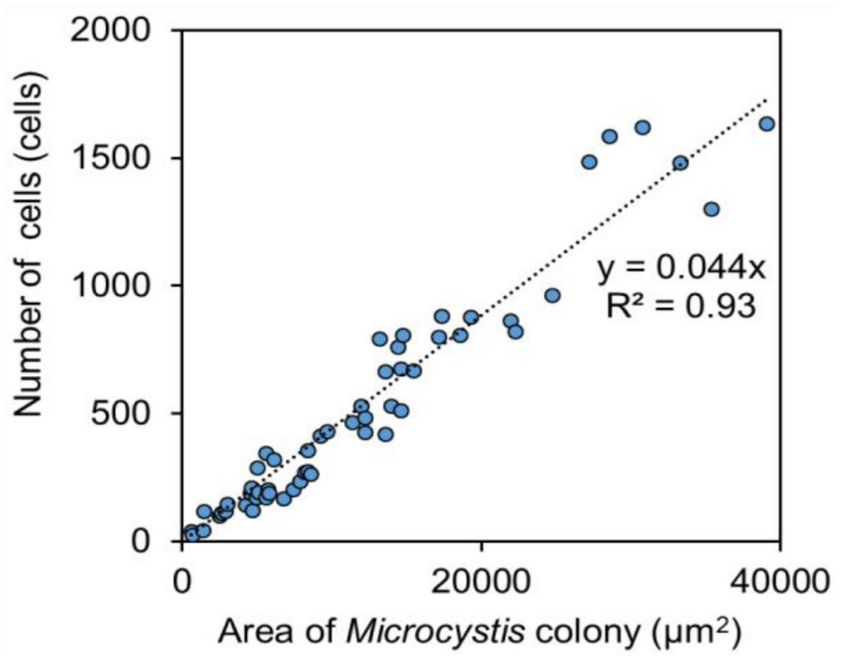

Fig. 5. Relationship between the number of cells in a colony and the 2D surface area of the colony.

\subsection{Bias Correction between the Two Methods and Development of a Model Algorithm}

The number of cells determined by the FlowCAM underestimated the actual cell numbers in a 3D colony. For a simple, fast, and accurate analysis using a FlowCAM, the difference between the cell numbers from the FlowCAM analysis and the actual cell numbers should be determined. To count the actual cell numbers using the conventional microscopic method, sonication was applied to break algal clumps. The number of Microcystis sp. cells was compared between the FlowCAM and the conventional micro scopic method after sonication (Fig. 6). It was found that the 


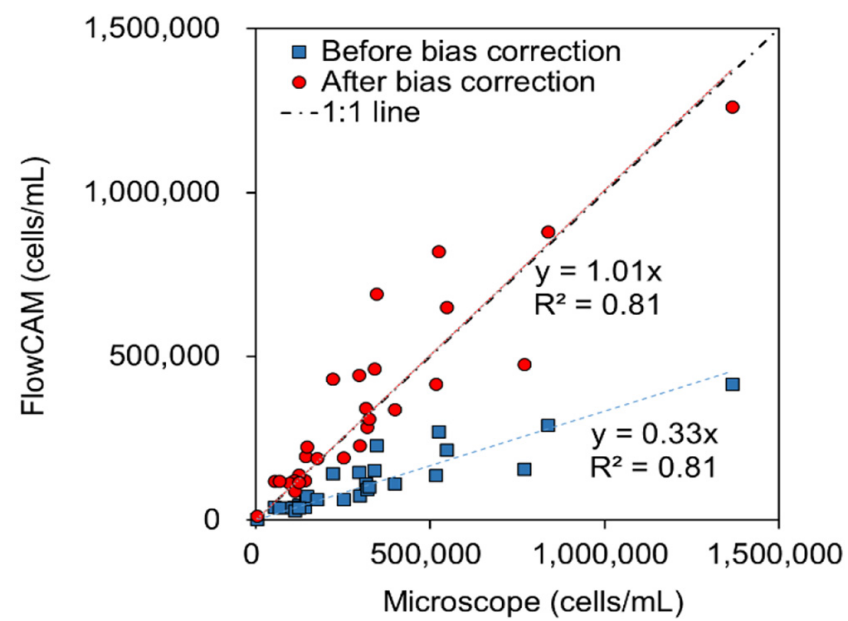

Fig. 6. Bias correction between the FlowCAM and the conventional microscopic method.

number of cells determined by the FlowCAM (plotted as blue squares in Fig. 6) underestimated the actual cell numbers after sonication, as the number of cells in a single Microcystis colony estimated from Eq. (1) represented the number of cells within the Microcystis colonies limited to 2D images. The slope of the relationship between measured cell numbers from the FlowCAM and microscope was 0.33 with an $\mathrm{R}^{2}$ of 0.81 .

To compensate for the loss of the actual cell numbers in cell counting, correction of this bias was needed. The correction factor was determined from the relationship of a 1 to 1 line and the slope of the relationship between the cell numbers measured by the FlowCAM and cell numbers measured by the microscopic inspection; the correction factor was determined as $1 / 0.33=3.03$. Thus, the correction factor of 3.03 was multiplied by the cell numbers originally estimated by the FlowCAM to correct the actual cell numbers. The corrected cell numbers measured by the FlowCAM are plotted as red circles in Fig. 6, where the slope of the relationship of measured cell numbers from the FlowCAM and microscope was 1.01 .

\subsection{Model Validation with Statistical Analysis}

The accuracy of the developed model algorithm was evaluated using three statistical methods, namely root mean square error-observation standard deviation ratio (RSR), Nash-Sutcliffe efficiency (NSE), and $\mathrm{R}^{2}$, using Eq. (2)-(4), which are commonly used for the evaluation of model performance [32, 33].

$$
\begin{aligned}
& \mathrm{RSR}=\frac{R M S E}{S T D E V_{o b s}}=\frac{\sum_{i=1}^{n}\left(M_{i}-O_{i}\right)^{2}}{\sqrt{\sum_{i=1}^{n}\left(O_{i}-\bar{O}\right)^{2}}} \\
& \mathrm{NSE}=\frac{\sum_{i=1}^{n}\left(O_{i}-\bar{O}\right)^{2}-\sum_{i=1}^{n}\left(M_{i}-O_{i}\right)^{2}}{\sum_{i=1}^{n}\left(O_{i}-\bar{O}\right)^{2}} \\
& R^{2}=\frac{\sum_{i=1}^{n}\left(O_{i}-\bar{O}\right)\left(M_{i}-\bar{M}\right)}{\sqrt{\sum_{i=1}^{n}\left(O_{i}-\bar{O}\right)^{2}} \sqrt{\sum_{i=1}^{n}\left(M_{i}-\bar{M}\right)^{2}}}
\end{aligned}
$$

where $n$ is the number of observations, $Q_{i}$ is the $\mathrm{i}^{\text {th }}$ observed value, $\bar{O}$ is the mean of $O_{i}, M_{i}$ is the $\mathrm{i}^{\text {th }}$ model-estimation value, and $\bar{M}$ is the mean of $M_{i}$.

The performance of the presented model algorithm (i.e., estimation of Microcystis sp. cell numbers in the water sample combining Eq. (1) and bias correction, as shown in Fig. 6) was analyzed based on cross-validation of observed and predicted cell numbers using RSR, NSE, and $\mathrm{R}^{2}$. For each iteration, 27 out of 28 samples were used for model calibration, and the remaining sample was used for validating the model algorithm; this step was iterated 28 times to measure residuals between observed data and model predictions for each of the samples. The results of the model performance are presented in Table 2. The average values of RSR, NSE, and $R^{2}$ of the FlowCAM model were $0.44,0.80$, and 0.80 , respectively. Better model performances are achieved if the values of RSR are closer to zero and NSE and $\mathrm{R}^{2}$ values are close to 1 ; the

\begin{tabular}{|c|c|c|c|}
\hline \multirow{2}{*}{ Iteration } & \multicolumn{3}{|c|}{ Statistical index } \\
\hline & RSR & NSE & R2 \\
\hline 1 & 0.44 & 0.80 & 0.80 \\
\hline 2 & 0.40 & 0.84 & 0.83 \\
\hline 3 & 0.37 & 0.86 & 0.85 \\
\hline 4 & 0.44 & 0.80 & 0.80 \\
\hline 5 & 0.44 & 0.80 & 0.80 \\
\hline 6 & 0.44 & 0.81 & 0.80 \\
\hline 7 & 0.43 & 0.82 & 0.81 \\
\hline 8 & 0.44 & 0.81 & 0.80 \\
\hline 9 & 0.44 & 0.81 & 0.81 \\
\hline 10 & 0.44 & 0.81 & 0.80 \\
\hline 11 & 0.44 & 0.80 & 0.80 \\
\hline 12 & 0.44 & 0.80 & 0.80 \\
\hline 13 & 0.44 & 0.81 & 0.81 \\
\hline 14 & 0.44 & 0.81 & 0.81 \\
\hline 15 & 0.47 & 0.78 & 0.78 \\
\hline 16 & 0.42 & 0.83 & 0.82 \\
\hline 17 & 0.45 & 0.80 & 0.79 \\
\hline 18 & 0.44 & 0.80 & 0.80 \\
\hline 19 & 0.44 & 0.81 & 0.80 \\
\hline 20 & 0.44 & 0.81 & 0.80 \\
\hline 21 & 0.44 & 0.81 & 0.80 \\
\hline 22 & 0.43 & 0.81 & 0.81 \\
\hline 23 & 0.44 & 0.81 & 0.80 \\
\hline 24 & 0.44 & 0.80 & 0.80 \\
\hline 25 & 0.44 & 0.81 & 0.81 \\
\hline 26 & 0.61 & 0.63 & 0.70 \\
\hline 27 & 0.41 & 0.83 & 0.85 \\
\hline 28 & 0.44 & 0.80 & 0.80 \\
\hline Min value & 0.37 & 0.63 & 0.70 \\
\hline Max value & 0.61 & 0.86 & 0.85 \\
\hline Average & 0.44 & 0.80 & 0.80 \\
\hline
\end{tabular}
model estimation can be considered satisfactory when RSR $<0.7$

Table 2. Performance Measures of the FlowCAM Model Statistics 
and NSE $\geq 0.65[32,33]$. Therefore, it was concluded that the developed model algorithm for cell number counting using the FlowCAM in this study was well calibrated, and a strong correlation was achieved between the observed and predicted cell numbers for the 28 samples.

\section{Discussion}

The manual measurement of Microcystis sp. using a microscope is a time-consuming process that requires highly trained expertise to avoid possible bias during visual inspection [24]. However, for effective water quality management, especially during algal bloom events such as those during the summer season, fast sampling and rapid analysis are required to make a quick, responsive decision to control algal bloom events properly. It is known that FlowCAMs can provide fast and unbiased results, which is valuable for water resource management regarding HABs in reservoirs and rivers [24, 25]. However, the quantification of algal blooms using FlowCAMs is still in the early stages of investigation, and the correction for accurate cell counting is not well explored. One challenge is counting cells in a $3 \mathrm{D}$ colony using a $2 \mathrm{D}$ analytical method. This study is the first to provide a systematic procedure and to develop a model algorithm for cell counts of Microcystis colonies considering the 3D form of the colony. The cross-validation of the developed model algorithm with unknown samples using the FlowCAM showed satisfactory performance for the estimation of Microcystis sp. cell numbers, which is considered adequate for practical application for rapid detection and analysis of Microcystis blooms in reservoirs and rivers with the following considerations.

First, the purpose of this study was to provide a new approach to facilitate cell counting of Microcystis sp. using a FlowCAM with a simple, but accurate analytical model and procedure, rather than to suggest specific values in the algorithm. For the water samples tested in this study, the bias correction factor (3.03) was determined based on the relationship of a 1 to 1 line and the slope of the relationship between cell numbers obtained by the FlowCAM and by microscopic observation. As samples randomly collected from various watersheds and sites were utilized for modeling, the model algorithm in this study could be considered generally applicable for HABs containing Microcystis sp. as predominant algal species. However, algal species and aggregation may be site-specific and thus FlowCAM library and model algorithm such as a slope in Eq. (1) or a bias correction factor (3.03 in this study) need to be developed initially for the FlowCAM use and the results may be different depending on sites. Using the proposed model algorithm and analytical procedures from this study, one can easily develop their own FlowCAM library and algorithm and utilize the FlowCAM for accurate cell counting for different sites and watersheds. Geomorphological comparison of a 3D ball and a 2D circle and further analytical analysis of the size of individual Microcystis sp. cells may also provide an alternative approach to improve the model algorithm.

Second, in this study, a filter tube with a diameter of $300 \mu \mathrm{m}$ coupled with a microscope of $\times 200$ magnification was used for algal cell imaging and counting. Although some of Microcystis colonies larger than $300 \mu \mathrm{m}$ may enter the filter tube by flow, the detection of Microcystis colonies was typically limited to colonies with a diameter less than $300 \mu \mathrm{m}$. Larger colonies can be detected using a next available filter tube larger than $300 \mu \mathrm{m}$ which is a $600 \mu \mathrm{m}$ filter tube with a microscope of $\times 200$ magnification. However, the use of different filter tubes with different magnifications for sample analysis can make the system more complicated with increased uncertainties, requiring further study. In practice, $300 \mu \mathrm{m}$ tube filter with a microscope of $\times 400$ magnification is typically used as it covers most dominant sizes of colonies found in water.

Lastly, the preciseness of the FlowCAM image library for the identification of Microcystis sp. was not evaluated in this study. The accuracy of the FlowCAM in the classification of Microcystis colonies itself is dependent on the appropriateness of the Microcystis sp. image library, which is individually developed by users. The development of an improved library could improve the applicability of the algorithm developed in this study to count the number of cells in Microcystis colonies.

\section{Conclusions}

In this study, a novel method for cell counting in Microcystis colonies was developed from water samples collected from two major watersheds in South Korea. The number of cells in Microcystis colonies obtained from the model algorithm was evaluated by cross-validation with three statistical methods, where the average values of RSR, NSE, and $\mathrm{R}^{2}$ of the FlowCAM model were $0.44,0.80$, and 0.80 , respectively. This study demonstrated the practical applicability of the FlowCAM for rapid and unbiased analysis of algal blooms, which is important for the proper management of water quality in freshwater systems and to provide safe water to the public. Further improvement of the precision of the FlowCAM library and the model algorithm for cell counting in algal colonies, as well as the extension of the library to other algae species, were left for future research.

\section{Acknowledgments}

This study was funded and supported by K-water (Korea Water Resources Corporation) to develop an innovative method for the effective management of harmful algal blooms in freshwater systems.

\section{References}

1. Cao J, Chu Z, Du Y, Hou Z, Wang S. Phytoplankton dynamics and their relationship with environmental variables of Lake Poyang. Hydrol. Res. 2016;47:249-260.

2. Cui YJ, Liu DF, Zhang JL, et al. Diel migration of Microcystis during an algal bloom event in the three Gorges Reservoir, China. Environ. Earth Sci. 2016;75:616.

3. Lehman P, Kurobe T, Lesmeister S, Baxa D, Tung A, Teh S. Impacts of the 2014 severe drought on the Microcystis bloom in San Francisco Estuary. Harmful Algae 2017;63:94-108.

4. Rowe M, Anderson E, Wynne T, et al. Vertical distribution of buoyant Microcystis blooms in a Lagrangian particle tracking 
model for short-term forecasts in Lake Erie. J. Geophys. Res. Oceans 2016;121:5296-5314.

5. Hyun B, Ju SJ, Ko AR, et al. Thermal effects on the growth and fatty acid composition of four harmful algal bloom species: Possible implications for ichthyotoxicity. Ocean Sci. J. 2016;51:333-342.

6. Bañares-España E, Del Mar Fernández-Arjona M, GarcíaSánchez M], et al. Sulphide resistance in the cyanobacterium Microcystis aeruginosa: A comparative study of morphology and photosynthetic performance between the sulphide-resistant mutant and the wild-type strain. Microb. Ecol. 2016;71:860-872.

7. Otten TG, Crosswell JR, Mackey S, Dreher TW. Application of molecular tools for microbial source tracking and public health risk assessment of a Microcystis bloom traversing 300 $\mathrm{km}$ of the Klamath River. Harmful Algae 2015;46:71-81.

8. Falconer IR. Algal toxins and human health. In: Hrubec J, ed. Quality and treatment of drinking water II. Berlin: Springer-Verlag; 1998. p. 57-73.

9. Codd GA, Morrison LF, Metcalf JS. Cyanobacterial toxins: Risk management for health protection. Toxicol. Appl. Pharmacol. 2005;203:264-272.

10. Carmichael WW, Azevedo S, An JS, et al. Human fatalities from cyanobacteria: Chemical and biological evidence for cyanotoxins. Environ. Health Perspect. 2001;109:663-668.

11. Taranu ZE, Gregory-Eaves I, Steele RJ, Beaulieu M, Legendre P. Predicting microcystin concentrations in lakes and reservoirs at a continental scale: A new framework for modelling an important health risk factor. Global Ecol. Biogeogr. 2017;26:625-637.

12. Oberholster PJ, Botha AM, Cloete TE. An overview of toxic freshwater cyanobacteria in South Africa with special reference to risk, impact and detection by molecular marker tools. Biokemistri 2005;17:57-71.

13. Dove A, Chapra SC. Long-term trends of nutrients and trophic response variables for the Great Lakes. Limnol. Oceanogr. 2015;60:696-721.

14. Wang C, Wu X, Tian C, et al. A quantitative protocol for rapid analysis of cell density and size distribution of pelagic and benthic Microcystis colonies by FlowCAM. J. Appl. Phycol. 2015;27:711-720.

15. Garmendia M, Revilla M, Zarauz L. Testing the usefulness of a simple automatic method for particles abundance and size determination to derive cost-effective biological indicators in large monitoring networks. Hydrobiologia 2013;704:231-252.

16. Paerl HW, Valdes LM, Pinckney JL, Piehler MF, Dyble J, Moisander PH. Phytoplankton photopigments as indicators of estuarine and coastal eutrophication. BioScience 2003;53: 953-964.

17. Mouillot D, Spatharis S, Reizopoulou S, et al. Alternatives to taxonomic-based approaches to assess changes in transitional water communities. Aquat. Conserv. 2006;16:469-482.

18. National Health and Medical Research Council (NHMRC). Guidelines for managing risks in recreational water. Australian Government, Canberra, Australia. 2008. p. 91-116.

19. Chorus I, Bartram J. Toxic cyanobacteria in water: A guide to their public health consequences, monitoring and management. 1st ed. New York: World Health Organization; 1999. p. 334-361.

20. Wood SA, Hamilton DP, Paul WJ, Safi KA, Williamson WM. New Zealand guidelines for cyanobacteria in recreational fresh waters. Wellington, New Zealand: Ministry for the Environment and Ministry of Health; 2009. p. 9-20.

21. Romero-Martínez L, Van Slooten C, Nebot E, Acevedo-Merino A, Peperzak L. Assessment of imaging-in-flow system (FlowCAM) for systematic ballast water management. Sci. Total Environ. 2017;603:550-561.

22. Sieracki CK, Sieracki ME, Yentsch CS. An imaging-in-flow system for automated analysis of marine microplankton. Mar. Ecol. Prog. Ser. 1998;168:285-296.

23. Dashkova V, Malashenkov D, Poulton N, Vorobjev I, Barteneva NS. Imaging flow cytometry for phytoplankton analysis. Methods 2017;112:188-200.

24. Poulton NJ, Martin JL. Imaging flow cytometry for quantitative phytoplankton analysis-FlowCAM. Microscopic and molecular methods for quantitative phytoplankton analysis. Intergovernmental Oceanographic Commission Manuals and Guides of UNESCO. 2010. p. 47-54.

25. Poulton NJ. FlowCAM: Quantification and classification of phytoplankton by imaging flow cytometry. In: Barteneva N, Vorobjev I, eds. Imaging flow cytometry: Methods and protocols in molecular biology. New York: Springer; 2016. p. 237-247.

26. Wong E, Sastri AR, Lin FS, Hsieh CH. Modified FlowCAM procedure for quantifying size distribution of zooplankton with sample recycling capacity. PloS One 2017;12:e0175235.

27. Milde AS, Richardson WB, Strauss EA, Larson JH, Vallazza J, Knights BC. Spatial and temporal dynamics of suspended particle characteristics and composition in navigation Pool 19 of the upper Mississippi River. River Res. Appl. 2017;33: 740-752.

28. Le Bourg B, Cornet-Barthaux V, Pagano M, Blanchot J. FlowCAM as a tool for studying small $(80-1000 \mu \mathrm{m})$ metazooplankton communities. J. Plankton Res. 2015;37:666-670.

29. Park J, Wang D, Lee WH. Evaluation of weir construction on water quality related to algal blooms in the Nakdong River. Environ. Earth Sci. 2018;77:408.

30. Briand E, Escoffier N, Straub C, Sabart M, Quiblier C, Humbert JF. Spatiotemporal changes in the genetic diversity of a bloom-forming Microcystis aeruginosa (cyanobacteria) population. ISME J. 2009;3:419-429.

31. Kurmayer R, Christiansen G, Chorus I. The abundance of microcystin-producing genotypes correlates positively with colony size in Microcystis sp. and determines its microcystin net production in Lake Wannsee. Appl. Environ. Microbiol. 2003;69:787-795.

32. Moriasi DN, Arnold JG, Van Liew MW, Bingner RL, Harmel $\mathrm{RD}$, Veith TL. Model evaluation guidelines for systematic quantification of accuracy in watershed simulations. T. ASABE 2007;50:885-900.

33. Golmohammadi G, Prasher S, Madani A, Rudra R. Evaluating three hydrological distributed watershed models: MIKE-SHE, APEX, SWAT. Hydrology 2014;1:20-39. 